\title{
Fire Behaviour of Timber-Concrete Composite Slabs
}

\author{
MARIO FONTANA, ANDREA FRANGI \\ Institute of Structural Engineering, ETH Zürich \\ ETH Hönggerberg, 8093 Zürich, Switzerland
}

\begin{abstract}
The experience of fire spread in old timber houses has resulted in a limitation of the use of timber in multi-storey buildings in the fire regulations of many countries. Timber-concrete composite elements show promise to overcome this handicap thus allowing an extended use of the sustainable building material timber. Results of fire tests on the behaviour of timberconcrete composite slabs are described and compared with design methods for timber in fire.
\end{abstract}

\section{KEYWORDS}

Timber-concrete composite slabs, fire resistance, burning rate, fire tests, shear connection, design methods for timber in fire, thermal stresses.

\section{INTRODUCTION}

In recent years the refurbishment of old buildings with timber floors has drawn attention to an efficient floor system, the timber-concrete composite slab. Compared to timber floors the main advantages of this type of composite structure are increased strength and stiffness, improved sound insulation and fire resistance. Timber-concrete composite slabs consist of timber members in the tensile zone, a thin concrete layer in the compression zone and the connection between timber and concrete. Besides the beam type floors, slab type floors using laminated wooden decks of sawn timber planks nailed together with the longer side of their cross-section vertical or glued laminated beams with the longer side of their cross-section horizontal are common.

The behaviour of timber-concrete composite slabs is essentially influenced by the shear connection between timber and concrete. A rigid connection between a concrete slab and timber beams improves the serviceability and resistance of such floors [1]. From the variety of connectors two types are being tested in an ongoing research project at our institute sponsored by the industrial partners Hilti AG, Schaan, Liechtenstein und SFS AG, Heerbrugg, Switzerland and the Swiss Commission for Technology Transfer and Innovation. The first type of connector consists of a threaded bar M12 (Hilti HVB) which is fixed in a $80 \mathrm{~mm}$ deep 
hole in the wood member with a special glue (Hilti HIT-WTR). The shear is transferred by 20 $\mathrm{mm}$ deep and $150 \mathrm{~mm}$ long grooves perpendicular to the span [2]. The second type of connector (SFS VB-48-7.5 $\times 100$ ) is a self-drilling screw with a collar to limit the screwing depth and a head for connection to the concrete. The threaded part has a length of $100 \mathrm{~mm}$ and a diameter of the net section of $4 \mathrm{~mm}$, the upper part of the connector is $50 \mathrm{~mm}$ long and has a diameter of $6 \mathrm{~mm}$. By arranging the connectors at $45^{\circ}$ inclination a virtual truss is formed with the timber and the concrete as girders and the connectors as diagonals. Such an arrangement improves the stiffness by a factor of about 3 compared to a vertical arrangement where the connector acts in bending [3].

\section{FIRE BEHAVIOUR OF TIMBER-CONCRETE COMPOSITE SLABS}

The fire resistance of timber-concrete composite elements is mainly determined by the behaviour of the timber and the connectors. Timber is a combustible material. When sufficient heat is applied to wood a process of thermal degradation (pyrolysis) occurs producing combustible gases, accompanied by a loss in weight and cross-section. A surface char layer is then formed, which because of its low thermal conductivity protects the interior of the timber section against heat. The amount of heat transferred by surface burning to the unburnt part of the wood decreases as the layer of char on the surface increases. Cracks in the timber can markedly increase the penetration of heat into the pyrolysis zone. The burning rate is mainly influenced by the specific density, the moisture content, the thermal conductivity and specific heat capacity. In a room fire the heat flux will influence the burning rate so that the fire behaviour is a rather complex phenomenon. For design purposes a simplified method based on a constant burning rate is commonly used.

Fire reduces the cross-section and the stiffness and strength of the timber close to the burning surface [4]. The stiffness and strength of wood depend on the temperature within the wood and significantly decrease with increasing temperature. At a temperature of about $200^{\circ} \mathrm{C}$ wood begins to undergo rapid thermal decomposition. The pyrolysis zone can be located between $200^{\circ} \mathrm{C}$ and $300^{\circ} \mathrm{C}$; the front of the char is found at a temperature of about $300^{\circ} \mathrm{C}$. Beeause of the good insulating behaviour of the char layer typical temperature profiles through burning timber members exhibit a steep temperature gradient. The temperature distribution within a burning wood member can be obtained by solving the partial differential equation for nonsteady-state heat conduction. Temperature field calculations with computer programs, which solve this equation by numerical integration, are usually based on a finite element analysis. Density, thermal conductivity and specific heat capacity of wood are a function of the temperature. Unfortunately, in most cases the properties have been determined over a narrow temperature range, with practically no information available at temperatures where thermal decomposition is occurring. Therefore the application of temperature calculations to wood taking into account charring is rather complex.

\section{FIRE TESTS}

When a timber-concrete composite structure is exposed to fire, it is of primary importance to know the changes in stiffness and strength experienced by the different components of the composite structure (timber, concrete and connector). An extensive testing programme was planned to enlarge the experimental background of design models for the fire resistance of timber-concrete composite floors. All fire tests were performed at the Swiss Federal Laborato- 
ries for Materials Testing and Research (EMPA) in Dübendorf. In a series of small scale tests, which were performed in EMPA's small furnace $(1.2 \times 1.0 \mathrm{~m})$ the behaviour of the connectors subjected to tension or shear was experimentally analysed. A series of tests on slabs, which were performed in EMPA's horizontal furnace $(5.0 \times 3.0 \mathrm{~m})$, looked at the global behaviour of timber-concrete composite slabs. All fire tests were performed using ISO-fire exposure.

\section{Tensile Tests}

The fire behaviour of the screws subjected to tension were experimentally analysed with the test arrangement shown in fig 1 . For each fire test two timber beams were placed in the small furnace and on each beam two connectors are tested. The $10 \mathrm{~cm}$ long threads of the screws were screwed $8 \mathrm{~cm}$ into the timber beams without pre-drilling the $2 \mathrm{~cm}$ high timber board. A similar test set up was used for the dowels, which were glued $8 \mathrm{~cm}$ into the wood members and were tested either in timber beams or in wooden decks made of timber planks nailed together with the longer side of their cross-section vertical. In the fire tests the temperature in selected locations, the deformation of the connectors and the tensile force were measured.
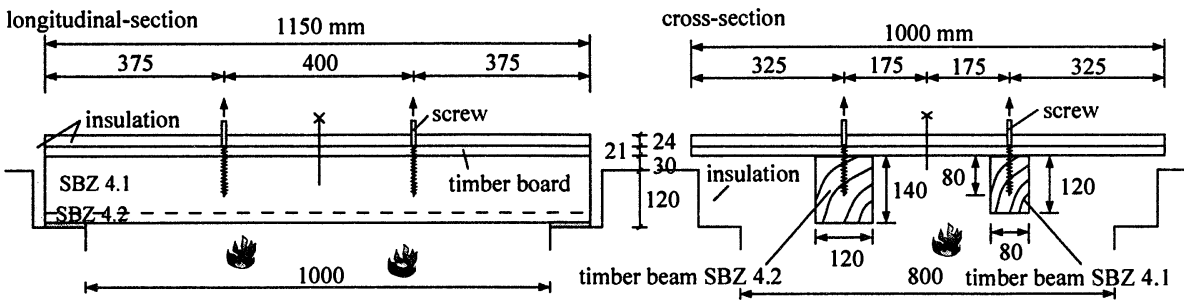

FIGURE 1. Test arrangement for the tensile tests with the screws subjected to the ISO-fire

The tests were performed using two different procedures:

- the specimens were exposed to the ISO-fire for 20,30 or 40 minutes with the permissible load applied to the connectors. If no failure has occurred after this time the load was increased until failure occurred (fire test of type I),

- the specimens were loaded with the permissible load and then exposed to the ISO-fire until failure (fire test of type II).

TABLE 1. Test parameters for the tensile tests with the screws subjected to the ISO-fire

\begin{tabular}{llllll}
\hline $\begin{array}{l}\text { Name of } \\
\text { test }\end{array}$ & $\begin{array}{l}\text { dimensions of } \\
\text { timber section }\end{array}$ & $\begin{array}{l}\text { connector-cover } \\
\text { side } / \text { bottom }\end{array}$ & type of wood & $\begin{array}{l}\text { gap between } \\
\text { beam and board }\end{array}$ & type of fire test \\
\hline SBZ 1.1 & $80 / 120 \mathrm{~mm}$ & $40 / 40 \mathrm{~mm}$ & solid & $0 \mathrm{~mm}$ & I $(30 \mathrm{~min})$. \\
SBZ 1.2 & $80 / 100 \mathrm{~mm}$ & $40 / 20 \mathrm{~mm}$ & solid & $0 \mathrm{~mm}$ & I $(30 \mathrm{~min})$. \\
\hline SBZ 2.0 & $120 / 140 \mathrm{~mm}$ & $60 / 60 \mathrm{~mm}$ & solid & $0 \mathrm{~mm}$ & I $(30 \mathrm{~min})$. \\
\hline SBZ 2.1 & $120 / 140 \mathrm{~mm}$ & $60 / 60 \mathrm{~mm}$ & solid & $0 \mathrm{~mm}$ & I $(30 \mathrm{~min})$. \\
SBZ 2.2 & $120 / 140 \mathrm{~mm}$ & $60 / 60 \mathrm{~mm}$ & glued laminated & $0 \mathrm{~mm}$ & I $(30 \mathrm{~min})$. \\
\hline SBZ 3.1 & $80 / 120 \mathrm{~mm}$ & $40 / 40 \mathrm{~mm}$ & solid & $3 \mathrm{~mm}$ & I $(30 \mathrm{~min})$. \\
SBZ 3.2 & $120 / 140 \mathrm{~mm}$ & $60 / 60 \mathrm{~mm}$ & solid & $3 \mathrm{~mm}$ & I (30 min.) \\
\hline SBZ 4.1 & $80 / 120 \mathrm{~mm}$ & $40 / 40 \mathrm{~mm}$ & solid & $0 \mathrm{~mm}$ & II (until failure) \\
SBZ 4.2 & $120 / 140 \mathrm{~mm}$ & $60 / 60 \mathrm{~mm}$ & solid & $0 \mathrm{~mm}$ & II (until failure) \\
\hline
\end{tabular}

The mean value of the resistance of the screws subjected to tension measured at room temperature was $12.4 \mathrm{kN} \pm 0.6 \mathrm{kN}$ (16 tests), that of the glued dowels in timber beams 21.8 
$\mathrm{kN} \pm 4.8 \mathrm{kN}$ ( 8 tests) and in timber planks $18.6 \mathrm{kN} \pm 2.5 \mathrm{kN}$ ( 8 tests). The screws failed when the tensile strength of the steel screw or the shear resistance between timber and screw was exceeded. The dowels always failed in shear between timber and glue. The permissible load for the connectors was chosen in accordance with the recommendations of the industrial partners: $3.6 \mathrm{kN}$ for the screws, $7 \mathrm{kN}$ for the dowels in timber beams and $6 \mathrm{kN}$ for the dowels in timber planks.

TABLE 2. Test parameters for the tensile tests with the glued dowels subjected to the ISO-fire

\begin{tabular}{llllll}
\hline $\begin{array}{l}\text { Name of } \\
\text { test }\end{array}$ & $\begin{array}{l}\text { dimensions of } \\
\text { timber section }\end{array}$ & $\begin{array}{l}\text { connector-cover } \\
\text { side } / \text { bottom }\end{array}$ & type of floor & type of wood & type of fire test \\
\hline HBZ 1.1 & $450 / 100 \mathrm{~mm}$ & $-/ 20 \mathrm{~mm}$ & timber planks & sawn planks & I (30 min.) \\
HBZ 1.2 & $450 / 140 \mathrm{~mm}$ & $-/ 60 \mathrm{~mm}$ & timber planks & sawn planks & I (30 min.) \\
\hline HBZ 2.1 & $450 / 120 \mathrm{~mm}$ & $-/ 40 \mathrm{~mm}$ & timber planks & sawn planks & I $(30 \mathrm{~min}$.) \\
HBZ 2.2 & $459 / 120 \mathrm{~mm}$ & $-/ 40 \mathrm{~mm}$ & timber planks & planed planks & I (30 min.) \\
\hline HBZ 3.1 & $450 / 120 \mathrm{~mm}$ & $-/ 40 \mathrm{~mm}$ & timber planks & sawn planks & II (until failure) \\
HBZ 3.2 & $450 / 140 \mathrm{~mm}$ & $-/ 60 \mathrm{~mm}$ & timber planks & sawn planks & II (until failure) \\
\hline HBZ 4.1 & $80 / 100 \mathrm{~mm}$ & $40 / 20 \mathrm{~mm}$ & timber beam & solid & II (until failure) \\
HBZ 4.2 & $80 / 140 \mathrm{~mm}$ & $40 / 60 \mathrm{~mm}$ & timber beam & solid & II (until failure) \\
\hline HBZ 5.1 & $80 / 120 \mathrm{~mm}$ & $40 / 40 \mathrm{~mm}$ & timber beam & solid & II (until failure) \\
HBZ 5.2 & $160 / 160 \mathrm{~mm}$ & $80 / 80 \mathrm{~mm}$ & timber beam & solid & I (30 min.) \\
\hline HBZ 6.0 & $120 / 140 \mathrm{~mm}$ & $60 / 60 \mathrm{~mm}$ & timber beam & solid & I (30 min.) \\
\hline HBZ 6.1 & $120 / 140 \mathrm{~mm}$ & $60 / 60 \mathrm{~mm}$ & timber beam & solid & I (30 min.) \\
HBZ 6.2 & $120 / 140 \mathrm{~mm}$ & $60 / 60 \mathrm{~mm}$ & timber beam & glued laminated & I (30 min.) \\
\hline HBZ 7.1 & $120 / 140 \mathrm{~mm}$ & $60 / 60 \mathrm{~mm}$ & timber beam & solid & II (until failure) \\
HBZ 7.2 & $160 / 160 \mathrm{~mm}$ & $80 / 80 \mathrm{~mm}$ & timber beam & solid & II (until failure) \\
\hline HBZ 8.1 & $450 / 100 \mathrm{~mm}$ & $-/ 20 \mathrm{~mm}$ & timber planks & sawn planks & II (until failure) \\
HBZ 8.2 & $450 / 120 \mathrm{~mm}$ & $-/ 40 \mathrm{~mm}$ & timber planks & sawn planks & II (until failure) \\
\hline
\end{tabular}

Tables 1 and 2 summarize the parameters of all fire tests with the two types of connectors. All specimens were made of spruce timber and for each specimen the density and the moisture content were measured. The density of the squared timber beams varied between 380 and 460 $\mathrm{kg} / \mathrm{m}^{3}$, that of the glued lamimated timber beams was about $495 \mathrm{~kg} / \mathrm{m}^{3}$, the timber planks of the nailed decks had a density between 380 and $460 \mathrm{~kg} / \mathrm{m}^{3}$. All specimens had a moisture content of 12 to $14 \%$.
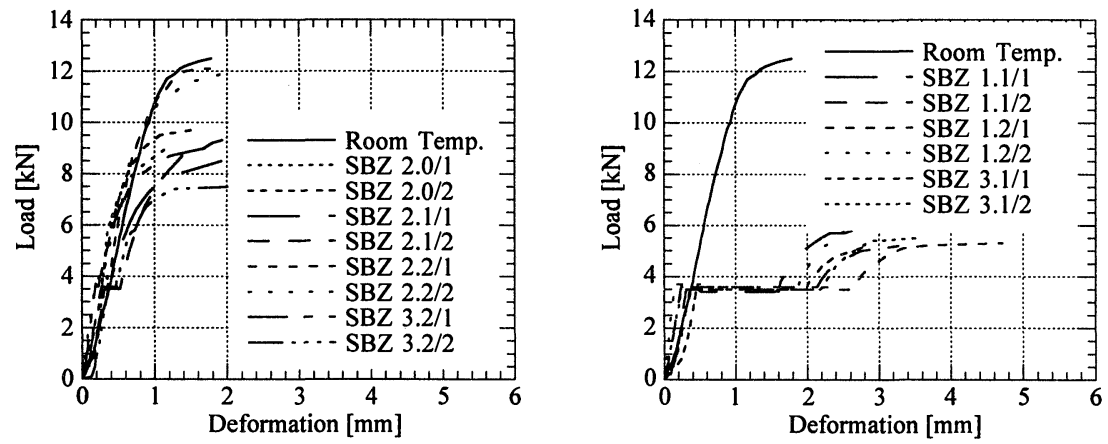

FIGURE 2. Load-deformation diagrams of the tensile tests of type I with the screws 
Fig. 2 shows the load-deformation diagrams of the tensile fire tests of type I with the screws. After 30 minutes of ISO-fire exposure the average residual tensile resistance of the screws in squared timber beams with $60 \mathrm{~mm}$ side cover was $8.9 \mathrm{kN}(72 \%$ of the tensile resistance at room temperature), that in squared timber beams with $40 \mathrm{~mm}$ side cover $5.6 \mathrm{kN}(45 \%)$. The load-deformation diagrams in fig. 2 (right) exhibit a horizontal plateau, due to the loss in stiffness of the wood around the screw during the fire tests at constant loading. The screws in the glued laminated timber beam with $60 \mathrm{~mm}$ side exhibited a residual tensile resistance of $12.0 \mathrm{kN}$, e.g. greater than in squared timber beams with the same dimensions. No significant difference was observed for the specimens with and without a gap between timber beam and timber board.

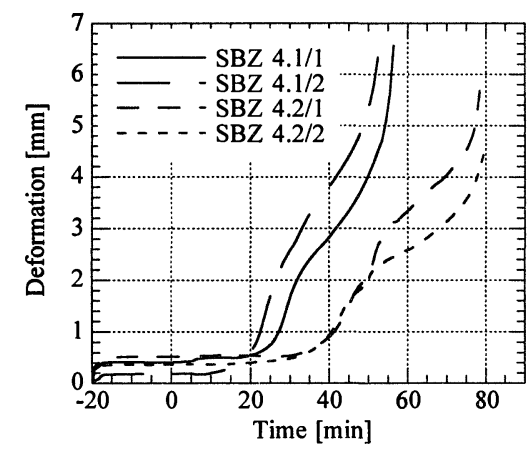

FIGURE 3. Deformation-time diagram of the tensile tests of type II with the screws

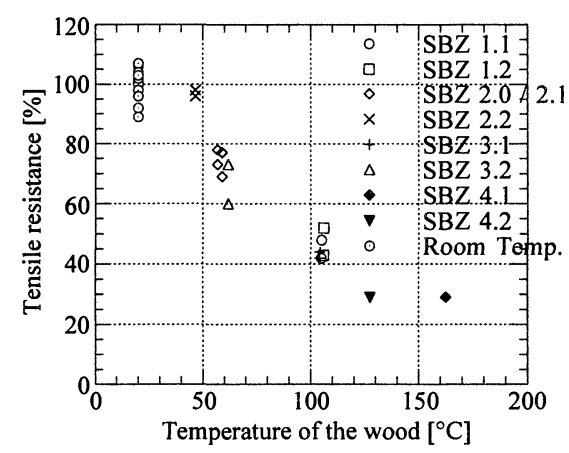

FIGURE 4. Tensile resistance of the screws as a function of the mean temp. of the wood

Fig. 3 illustrates the deformation-time diagram of the tensile fire tests of type II with the screws (beginning of fire test is indicated with time zero). The deformation of the screws in the timber beam with $40 \mathrm{~mm}$ side cover began to increase steeply after $20 \mathrm{~min}$. Failure occurred after $54 \mathrm{~min}$. With $60 \mathrm{~mm}$ side cover the screws exhibited no additional deformation up to around $40 \mathrm{~min}$. and failed after $78 \mathrm{~min}$. In agreement with the measured charring rate of about $0.8 \mathrm{~mm} / \mathrm{min}$. a time-lag of about $24 \mathrm{~min}$. for the deformation curves between the specimens with 40 and $60 \mathrm{~mm}$ side cover was observed. Because of the uniform heat flow to the screws from the side of the timber beams no significant temperature gradient was measured in the axis of the connection. Fig. 4 shows the residual tensile resistance (\% of the tensile resistance at room temperature) as a function of the average temperature of the wood around the connection. A linear loss in tensile resistance as a function of the rise of the mean wood temperature is observed. The average residual tensile resistance of the screw at about $60^{\circ} \mathrm{C}$ is $72 \%$ of the tensile resistance at room temperature, while at about $105^{\circ} \mathrm{C}$ it decreases to $45 \%$ of the tensile resistance at room temperature.

Fig. 5 illustrates the deformation-time diagrams of the tensile fire tests of type II with the glued dowels. The dowels in timber beams with $40 \mathrm{~mm}$ side cover failed after 23 minutes of ISO-fire exposure, with $60 \mathrm{~mm}$ side cover after $44 \mathrm{~min}$. and with $80 \mathrm{~mm}$ side cover after 68 min. In agreement with the measured charring rate of about $0.8 \mathrm{~mm} / \mathrm{min}$. a time-lag of about 23 minutes for the deformation curves between the specimens with 40,60 and $80 \mathrm{~mm}$ side cover was observed. Due to the heat flow only from below for the dowels in the wooden slabs made of nailed timber planks failure occurred later than in timber beams and the results are more subject to local burning differences of the wooden decks. 

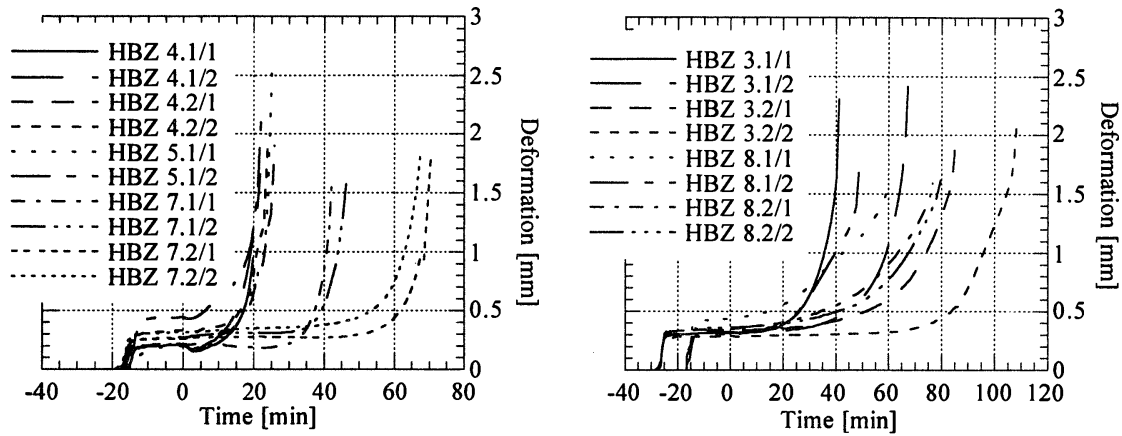

FIGURE 5. Time-deformation diagrams of the tensile tests of type II with the glued dowels

In the fire tests with glued dowels the temperature in the glue was measured by a reference dowel (fig. 6). Fig. 7 shows the residual tensile resistance as a function of the average temperature of the glue. Unlike the screws the glued dowels did not show a reduction in tensile resistance until about $50^{\circ} \mathrm{C}$. Beginning from this temperature a strong loss in tensile resistance was observed as the temperature increased. For the permissible load applied to the dowel in timber beams a critical temperature of about $80^{\circ} \mathrm{C}$ was observed. In accordance with the lower permissible load applied and due to the temperature gradient in the glue the critical temperature of the dowel in wooden decks of nailed timber planks was higher. Similar results with different glues were obtained in [5].

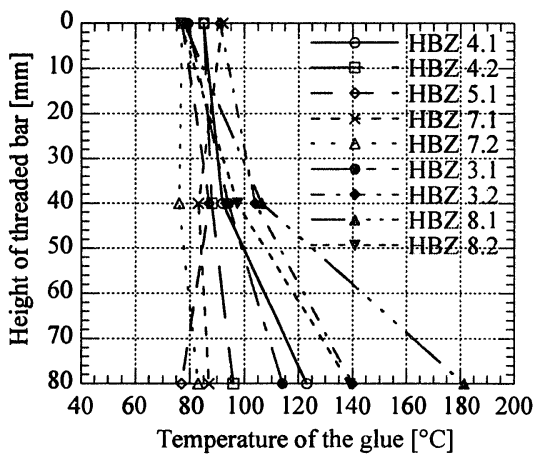

FIGURE 6. Temperature profiles of the glue around the reference dowels at failure

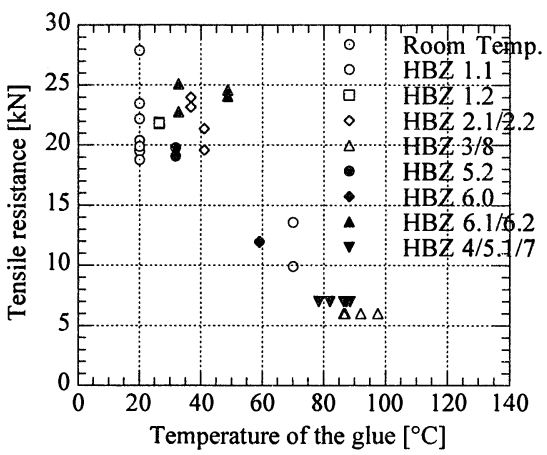

FIGURE 7. Tensile resistance of the dowels as a function of the mean temp. of the glue

\section{Shear Tests with Screws}

The fire behaviour of the screws subjected to shear were experimentally analysed with the test arrangement in fig. 8. For each fire test two timber-concrete composite elements with three pairs of screws arranged at $\pm 45^{\circ}$ were placed in the small furnace. In the tests the temperature in selected locations, the relative deformation between timber beam and concrete slab and the compressive load on the concrete slab were measured. The average maximum load for the composite elements with three pairs of screws subjected to shear at room temperature was 
$43.0 \mathrm{kN} \pm 4.7 \mathrm{kN}$ (4 tests). At failure the screws subjected to tension were pulled out of the timber, those in compression were bent.

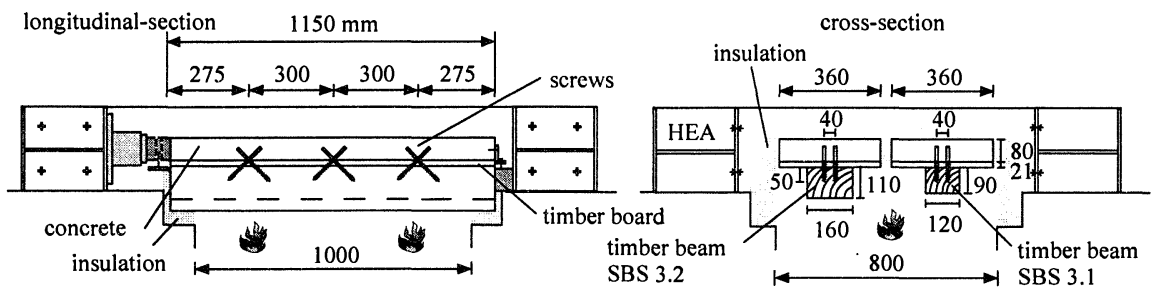

FIGURE 8. Test arrangement for the shear tests with the screws subjected to the ISO-fire

The fire test procedures followed the same principles as for the tensile tests of type I. The load level for the fire tests was fixed at $14 \mathrm{kN}$. Table 3 illustrates the parameters of all fire tests with the screws. All specimens were made of spruce timber. The density of the squared timber beams varied between 360 and $400 \mathrm{~kg} / \mathrm{m}^{3}$, that of the glued laminated timber beam was 470 $\mathrm{kg} / \mathrm{m}^{3}$. All specimens had a moisture content of $10 \%$.

TABLE 3. Test parameters for the shear tests with the screws subjected to the ISO-fire

\begin{tabular}{llllll}
\hline $\begin{array}{l}\text { Name of } \\
\text { test }\end{array}$ & $\begin{array}{l}\text { dimensions of } \\
\text { timber section }\end{array}$ & $\begin{array}{l}\text { dimensions of } \\
\text { concrete section }\end{array}$ & $\begin{array}{l}\text { connector-cover } \\
\text { side / bottom }\end{array}$ & type of wood & $\begin{array}{l}\text { type of fire } \\
\text { test }\end{array}$ \\
\hline SBS 1.1 & $120 / 70 \mathrm{~mm}$ & $360 / 80 \mathrm{~mm}$ & $40 / 20 \mathrm{~mm}$ & solid & I $(30 \mathrm{~min})$. \\
SBS 1.2 & $160 / 110 \mathrm{~mm}$ & $360 / 80 \mathrm{~mm}$ & $60 / 60 \mathrm{~mm}$ & solid & I $(30 \mathrm{~min})$. \\
\hline SBS 2.1 & $120 / 90 \mathrm{~mm}$ & $360 / 80 \mathrm{~mm}$ & $40 / 40 \mathrm{~mm}$ & solid & I $(30 \mathrm{~min})$. \\
SBS 2.2 & $120 / 90 \mathrm{~mm}$ & $360 / 80 \mathrm{~mm}$ & $40 / 40 \mathrm{~mm}$ & glued laminated & I $(30 \mathrm{~min})$. \\
\hline SBS 3.1 & $120 / 90 \mathrm{~mm}$ & $360 / 80 \mathrm{~mm}$ & $40 / 40 \mathrm{~mm}$ & solid & I $(40 \mathrm{~min})$. \\
SBS 3.2 & $160 / 110 \mathrm{~mm}$ & $360 / 80 \mathrm{~mm}$ & $60 / 60 \mathrm{~mm}$ & solid & I $(40 \mathrm{~min})$. \\
\hline
\end{tabular}

Fig. 9 shows the load-deformation diagram of the shear fire tests with the screws. After 30 minutes of ISO-fire exposure the average residual resistance of the composite element with 60 $\mathrm{mm}$ side cover was $33.9 \mathrm{kN}$ ( $79 \%$ of the resistance at room temperature), that in composite members with $40 \mathrm{~mm}$ side cover $18.0 \mathrm{kN}$ ( $42 \%$ of the resistance at room temperature).

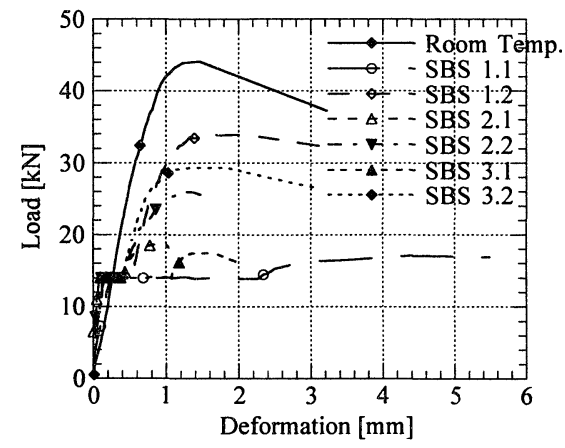

FIGURE 9. Load-deformation diagram of the shear tests with the screws

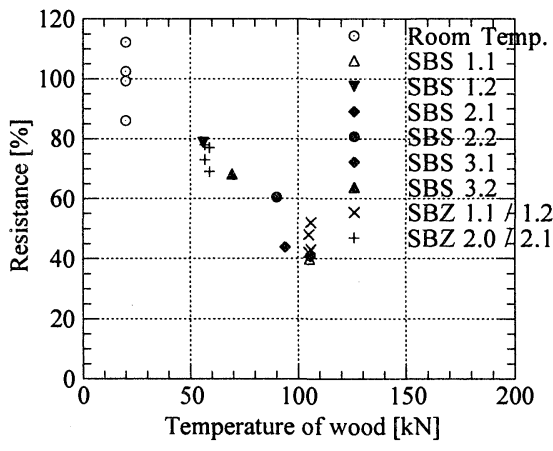

FIGURE 10. Resistance of the shear and tensile tests as a function of the wood temp. 
The specimen made with the glued laminated timber beam and $40 \mathrm{~mm}$ side cover exhibited a residual resistance of $26.0 \mathrm{kN}$, e.g. greater than that of the specimen of squared timber beam with the same dimensions. The relation between the residual resistance of the shear and tensile fire tests and the average temperature of the wood around the connection is reported in fig. 10. By arranging the screws at $\pm 45^{\circ}$ they transfer shear like tension and compression diagonals in a virtual truss. Therefore the screws exhibit the same linear resistance reduction in the shear fire tests as in the tensile fire tests. As soon as the fire tests started, a continuous increase of the deformation between timber beam and concrete slab (slip) was observed. This phenomenon is due to thermal strains in the timber beams combined with a loss in stiffness of the screws as a function of a rise of the wood temperature around the screw.

\section{Shear Tests with Glued Dowels}

The fire behaviour of the grooved connection with glued dowels subjected to shear were experimentally analysed with the test arrangement in fig. 11 . For each fire test two timber-concrete composite elements with two glued dowels placed in $20 \mathrm{~mm}$ deep, $150 \mathrm{~mm}$ long grooves were tested in the small furnace. In the tests the temperature in selected locations, the relative deformation between timber beam and concrete slab and the compressive load on the concrete slab were measured.

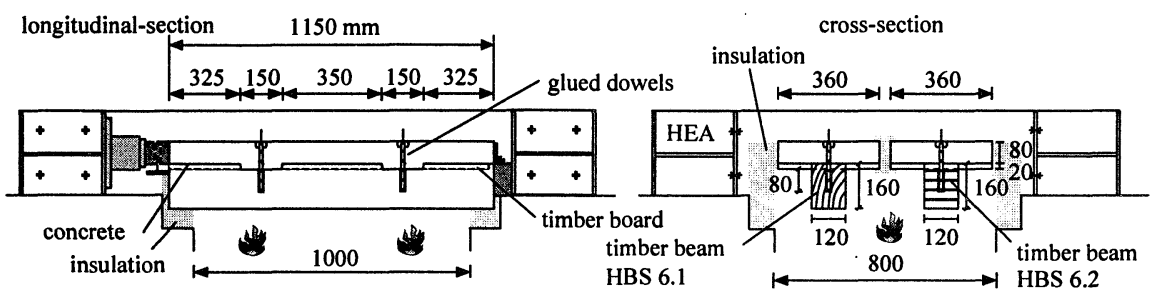

FIGURE 11. Test arrangement for the shear tests with the dowels subjected to the ISO-fire

The average maximum load for the composite elements with two grooves depends on the width of the timber beams. With $80 \mathrm{~mm}$ wide timber beams it was $148 \mathrm{kN}$, with $120 \mathrm{~mm} 201$ $\mathrm{kN}$ and with $160 \mathrm{~mm} 233 \mathrm{kN}$. This type of connection exhibited a great plastic deformation capability. The failure was due to the lokal compressive/shear failure of the wood of the groove front combined with dowel bending.

TABLE 4. Test parameters for the shear tests with dowels subjected to the ISO-fire

\begin{tabular}{llllll}
\hline $\begin{array}{l}\text { Name of } \\
\text { test }\end{array}$ & $\begin{array}{l}\text { dimensions of } \\
\text { timber section }\end{array}$ & $\begin{array}{l}\text { dimensions of } \\
\text { concrete section }\end{array}$ & $\begin{array}{l}\text { connector-cover } \\
\text { side } / \text { bottom }\end{array}$ & type of wood & type of fire test \\
\hline HBS 5.1 & $80 / 140 \mathrm{~mm}$ & $360 / 80 \mathrm{~mm}$ & $40 / 40 \mathrm{~mm}$ & solid & I $(20 \mathrm{~min})$. \\
HBS 5.2 & $120 / 160 \mathrm{~mm}$ & $360 / 80 \mathrm{~mm}$ & $60 / 60 \mathrm{~mm}$ & solid & I $(20 \mathrm{~min})$. \\
\hline HBS 6.1 & $120 / 160 \mathrm{~mm}$ & $360 / 80 \mathrm{~mm}$ & $60 / 60 \mathrm{~mm}$ & solid & I $(30 \mathrm{~min})$. \\
HBS 6.2 & $120 / 160 \mathrm{~mm}$ & $360 / 80 \mathrm{~mm}$ & $60 / 60 \mathrm{~mm}$ & glued laminated & I $(30 \mathrm{~min})$. \\
\hline HBS 7.1 & $160 / 180 \mathrm{~mm}$ & $360 / 80 \mathrm{~mm}$ & $80 / 80 \mathrm{~mm}$ & solid & I $(30 \mathrm{~min})$. \\
HBS 7.2 & $160 / 180 \mathrm{~mm}$ & $360 / 80 \mathrm{~mm}$ & $80 / 80 \mathrm{~mm}$ & solid & I $(30 \mathrm{~min})$. \\
\hline
\end{tabular}

The fire test procedures followed the same principles as for the tensile tests of type I. The load level for the fire tests was fixed at about a third of the maximum load at room temperature. Table 4 shows the parameters of all fire tests with the glued dowels. All specimens were made 
of spruce timber. The density of the squared timber beams varied between 365 and $385 \mathrm{~kg} / \mathrm{m}^{3}$, that of the glued lamimated timber beam was $487 \mathrm{~kg} / \mathrm{m}^{3}$. All specimens had a moisture content of 12 to $13 \%$.

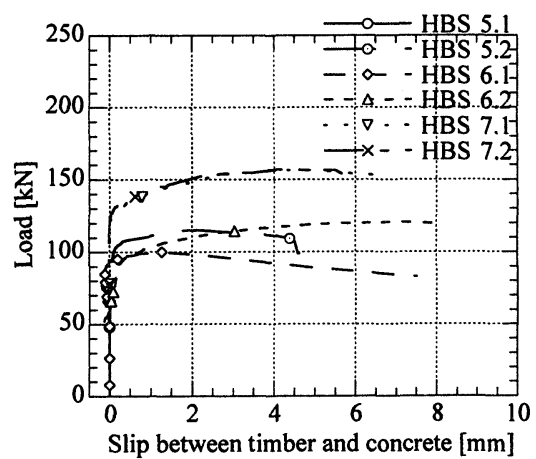

FIGURE 12. Load-deformation diagram of the shear tests with the glued dowels

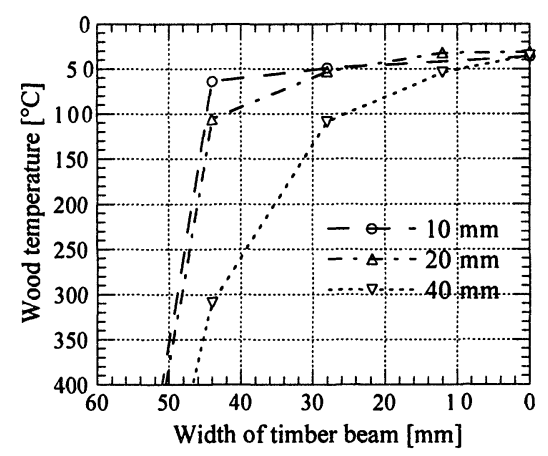

FIGURE 13. Temperature gradient after 30 min. ISO-fire for a $120 \mathrm{~mm}$ wide timber beam

Fig. 12 shows the load-deformation diagram of the shear fire tests with the grooved connections and Hilti dowels. After 20 minutes of ISO-fire exposure the residual resistance of the composite element with $80 \mathrm{~mm}$ wide timber beam was $58.3 \mathrm{kN}(39 \%$ of the resistance at room temperature), that of the composite member with $120 \mathrm{~mm}$ wide timber beam $115.2 \mathrm{kN}$ (57\%). After 30 minutes of ISO-fire exposure the residual resistance of the composite element with $120 \mathrm{~mm}$ wide timber beam was $100.1 \mathrm{kN}(50 \%)$, that of the composite members with $160 \mathrm{~mm}$ wide timber beams $156.8 \mathrm{kN}(67 \%)$. The specimen made with the glued laminated $120 \mathrm{~mm}$ wide timber beam exhibited a residual resistance of $120.7 \mathrm{kN}$, e.g. greater than that of the specimen of squared timber beam with the same dimensions. During all fire tests no loss in stiffness (e.g. no slip beetween timber beam and concrete slab) was observed. The observed loss in shear resistance of the connection depends on the reduced cross section near the groove and the wood temperature in the groove plane. The glued dowels avoid vertical separation of timber and concrete and have a secondary role with regard to stiffness. Fig. 13 illustrates the temperature gradient after $30 \mathrm{~min}$. ISO-fire exposure for a $120 \mathrm{~mm}$ wide and $160 \mathrm{~mm}$ high timber beam (the fig. shows only half of the cross-section) at different depths from the surface of the timber beam (o:10 mm, $\Delta: 20 \mathrm{~mm}$ and $\nabla: 40 \mathrm{~mm}$ ). The single points in the fig. indicate the points where the temperature was measured. As shown in fig. 13 a $20 \mathrm{~mm}$ high timber board protects the grooves from the fire exposure.

\section{Testing of a Slab}

A first fire test with a timber-concrete composite slab made of sawn timber planks 100 and $120 \mathrm{~mm}$ high and a 80 to $100 \mathrm{~mm}$ thick concrete layer was performed (fig. 14). The composite slab had no connectors between timber planks and concrete layer. The shear connection between concrete and timber was realised by micromechanical interlock between concrete and the raw sawn surface of the timber planks with alternating heigth of 100 and $120 \mathrm{~mm}$. The slab was loaded at about a third of the span. The level of the load $F_{\text {fire }}$ was fixed in such a way that the maximum bending moment corresponded to that in a slab of $6.5 \mathrm{~m}$ span, which is 
loaded by a permanent load of $1.5 \mathrm{kN} / \mathrm{m}^{2}$ and a reduced accompanying live load of $0.3 * 3.0$ $\mathrm{kN} / \mathrm{m}^{2}$ according to the Swiss reference actions code, which allows for a reduction of the variable load due to the low probabilty of coincidence of the maximum variable load and fire. In the fire test the temperature in selected locations, the deflection, the curvature and the relative deformation between timber planks and concrete slab were measured.

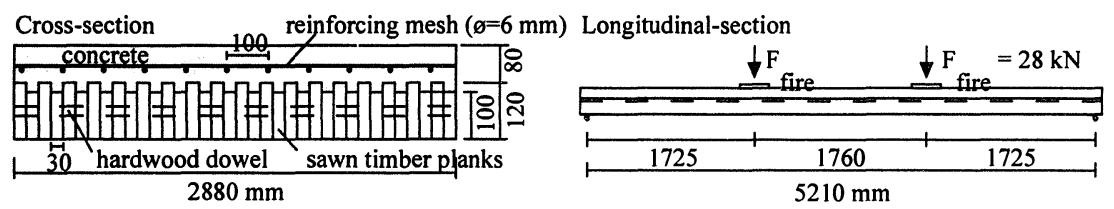

FIGURE 14. Cross-section and longitudinal-section of the timber-concrete composite slab

The timber concrete composite slab, which exhibited no slip between concrete and timber during the test, was exposed to 90 minutes of ISO-fire with the load $\mathrm{F}_{\text {fire }}$. After the fire test the load was increased until failure occurred at around $2.8^{*} \mathrm{~F}_{\text {fire }}$. An average charring rate of about $0.72 \mathrm{~mm} / \mathrm{min}$ was measured. Fig. 15 shows the increase of the slab deflection $\mathrm{w}$ as a function of the time (beginning of fire test is indicated with time zero). Fig. 16 illustrates the temperature profiles measured in the timber planks. After 90 minutes of ISO-fire exposure the concrete layer exhibited a temperature of $20^{\circ} \mathrm{C}$ and one third of the timber cross-section a temperature of less than $100^{\circ} \mathrm{C}$.

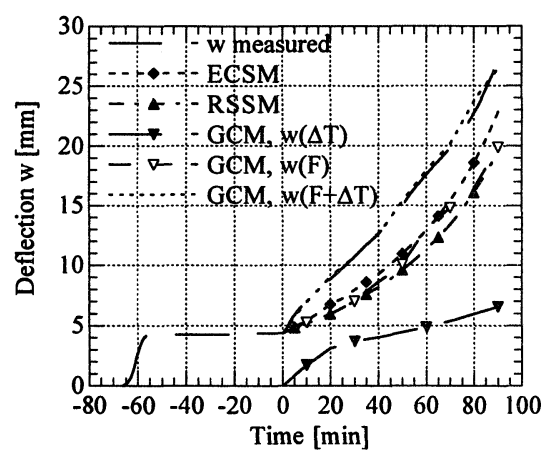

FIGURE 15. Deflection-time diagram of the timber-concrete composite slab

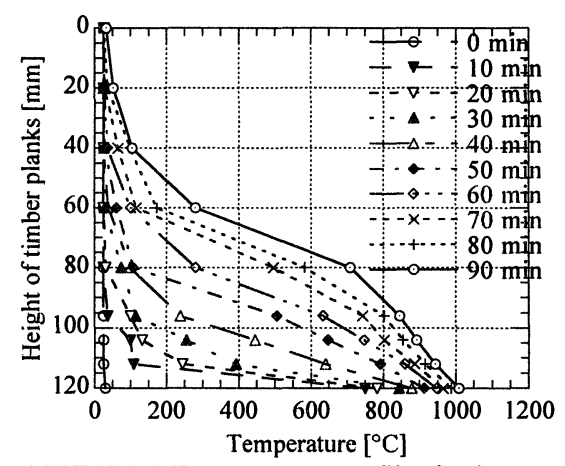

FIGURE 16. Temperature profiles in the timber-concrete composite slab

The increase of the deflection $\mathrm{w}$ during the fire test was calculated using two different simplified design methods, the Effective Cross-Section Method (ECSM) and the Reduced Strength and Stiffness Method (RSSM), which are described in the Eurocode 5, Part 1-2 [6]. The ECSM represents the strength and stiffness reduction by an effective cross section e.g. adding an additional depth to the charred depth, while the RSSM applies a general reduction of stiffness and strength to the residual section depending on the ratio between the exposed boundary $p$ and the residual section $A_{r}$. A charring rate $\beta_{0}$ of $0.7 \mathrm{~mm} / \mathrm{min}$ is assumed.

To consider the influence of the thermal elongation on the behaviour of the timber-concrete composite slab, a General Calculation Method (GCM) was used (fig. 17). The cross-section is 
supposed to be composed of $\mathrm{n}$ hypothetical longitudinal unconnected layers with different strength and stiffness properties $\left(E_{i}\right)$ depending on the measured temperature $\left(T_{i}\right)$.

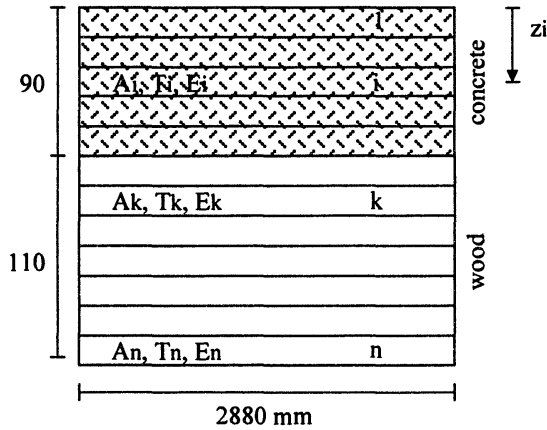

FIGURE 17. Simplified design methods for timber in fire: a General Calculation Method (GCM)

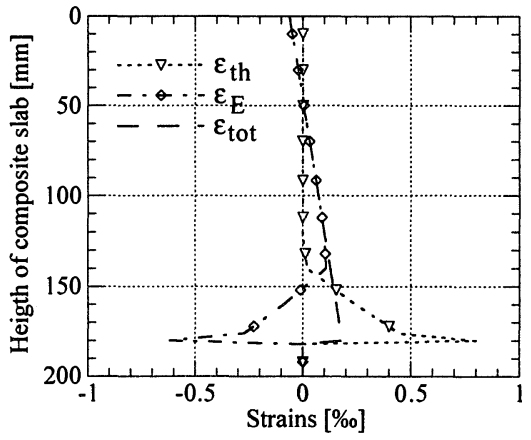

FIGURE 18. Thermal strains $\varepsilon_{\text {th }}$, internal strains $\varepsilon_{\mathrm{E}}$ and total strains $\varepsilon_{\text {tot }}$ after 30 minutes of the ISO-fire

The sharp temperature gradient (see fig. 16) will induce thermal elongations (strains $\varepsilon_{\text {th,i }}$ ) which are not linearly distributed (see fig. 18).

$$
\varepsilon_{t h, i}(t)=\alpha_{T} \cdot T_{i}(t) \quad \text { With } \alpha_{T} \text { : coefficient of thermal expansion }
$$

To fullfill the hypothesis of Bernoulli-Navier of a plane section internal elongations (strains $\left.\varepsilon_{\mathrm{E}, \mathrm{i}}\right)$ producing residual thermal stresses $\sigma_{\mathrm{E}, \mathrm{i}}$ must be introduced (see fig. 18).

$$
\varepsilon_{E, i}(t)=\varepsilon_{t o t, i}(t)-\varepsilon_{t h, i}(t) \quad \sigma_{E, i}(t)=E_{i}\left(T_{i}\right) \cdot \varepsilon_{E, i}(t)
$$

For a statically determinate system without external loads the total elongations (strains $\varepsilon_{\text {tot,i) }}$ ) are found by imposing that the equivalent action effects $\mathrm{N}_{\mathrm{E}}(3)$ and $\mathrm{M}_{\mathrm{E}}(4)$ for the residual thermal stresses $\sigma_{\mathrm{E}, \mathrm{i}}$ are zero.

$$
\begin{aligned}
& N_{E}(t)=\sum_{i=1}^{n} \sigma_{E, i}(t) \cdot A_{i}=\sum_{i=1}^{n}\left\{\varepsilon_{t o t, i}(t)-\varepsilon_{t h, i}(t)\right\} \cdot E_{i}\left(T_{i}\right) \cdot A_{i}=0 \\
& M_{E}(t)=\sum_{i=1}^{n} \sigma_{E, i}(t) \cdot A_{i} \cdot z_{i}(t)=\sum_{i=1}^{n}\left\{\varepsilon_{t o t, i}(t)-\varepsilon_{t h, i}(t)\right\} \cdot E_{i}\left(T_{i}\right) \cdot A_{i} \cdot z_{i}(t)=0
\end{aligned}
$$

Fig. 18 shows the thermal strains $\varepsilon_{\mathrm{th}}$, the internal strains $\varepsilon_{\mathrm{E}}$ and the total strains $\varepsilon_{\mathrm{tot}}$ calculated with the GCM after 30 minutes of the ISO-fire exposure. In fig. 14 the measured deflection w during the fire test and the calculated deflections using the three different simplified design methods ECSM, RSSM and GCM,w(F) are compared. The stiffness property E at room temperature was calculated from the deflections measured before the fire test. Further the diagram shows the increase of the deflection $\mathrm{GCM}, \mathrm{w}(\Delta \mathrm{T})$ due to the influence of the thermal elongation. The ECSM, the RSSM and the GCM,w(F), which do not consider the influence of the thermal elongation are unable to predict exactly the sharp increase of the deflection of the 
timber-concrete composite at the beginning of the fire test, while the $\mathrm{GCM}, \mathrm{w}(\mathrm{F}+\Delta \mathrm{T})$, which considers the effects of the thermal elongation shows an excellent prediction of the increase of the deflection during the fire test.

Two more slab tests designed for a resistance of one hour were performed at the beginning of 1999 with beam type slabs one with grooves and glued dowels and one with screws. The beam type slab with grooves and Hilti dowels failed after $63 \mathrm{~min}$. ISO-fire exposure, the beam type slab with screws after $67 \mathrm{~min}$. Detailed results of these fire tests will be published later.

\section{CONCLUSIONS}

In a series of small scale fire tests the behaviour of the screwed and glued connectors for timber-concrete composite slabs subjected to tension or shear was experimentally analysed. The screws exhibited a similar linear resistance reduction in the tensile fire tests and in the shear fire tests as a function of the rise of the wood temperature around the connectors. Unlike the screws the dowels did not show a reduction in tensile resistance up to around $50^{\circ} \mathrm{C}$. Beginning from this temperature a strong loss in tensile resistance was observed as the temperature of the glue increased. In the shear fire tests the grooved connections with glued dowels exhibited a loss in resistance depending on the reduced cross section near the groove and the wood temperature in the groove plane.

A series of tests on slabs looked at the global behaviour of timber-concrete composite slabs and permited to check the fire design method for timber-concrete composite slabs using the strength and stiffness models from the fire tests on the connectors. A timber-concrete composite slab made of nailed timber planks and a concrete layer designed for a fire resistance of 90 minutes and two beam type slabs designed for a fire resistance of 60 minutes were tested. The calculation method developed on the basis of the strength and stiffness models and the fire test results were in good agreement.

\section{REFERENCES}

1. Blass, H.J., Ehlbeck, J., van der Linden, M.L.R. und Schlager, M., Trag- und Verformungsverhalten von Holz-Beton-Verbundkonstruktionen, Bericht T 2710, Universität Karlsruhe, 1995

2. Natterer, J., Hoeft, M., Holz-Beton-Verbundkonstruktionen, Entwicklung eines neuen Verbin-dungssystems, Forschungsbericht CERS Nr. 1638, IBOIS, Ecole Polytechnique Fédérale Lausanne, März 1992

3. Timmermann, K., Meierhofer, U., Holz-Beton-Verbundkonstruktionen, Untersuchungen und Entwicklungen zum mechanischen Verbund von Holz und Beton, Forschungsbericht 115/30, EMPA, Abteilung 155, Oktober 1993

4. Glos, P. und Henrici, D., Festigkeit von Bauholz bei hohen Temperaturen, Abschlussbericht 87505, Institut für Holzforschung der Universität München, 1990

5. Barber, D.J., Buchanan, A.H, Fire Resistance of Epoxied Steel Rods in Glulam Timber, Research Report 94/1, Dep. of Civil Eng., University of Canterbury, Christchurch, New Zealand

6. ENV 1995-1-2 "Eurocode 5": Design of timber structures, Part 1-2 General rules, supplemenary rules for structural fire design, 1994 